\title{
Inventory Centralization Decision Framework for Spare Parts
}

\author{
Gregersen, Nicklas; Herbert-Hansen, Zaza Nadja Lee
}

Published in:

Production Engineering

Link to article, DOI:

$10.1007 / \mathrm{s} 11740-018-0814-3$

Publication date:

2018

Document Version

Peer reviewed version

Link back to DTU Orbit

Citation (APA):

Gregersen, N., \& Herbert-Hansen, Z. N. L. (2018). Inventory Centralization Decision Framework for Spare Parts. Production Engineering, 12(3-4), 353-365. https://doi.org/10.1007/s11740-018-0814-3

\section{General rights}

Copyright and moral rights for the publications made accessible in the public portal are retained by the authors and/or other copyright owners and it is a condition of accessing publications that users recognise and abide by the legal requirements associated with these rights.

- Users may download and print one copy of any publication from the public portal for the purpose of private study or research.

- You may not further distribute the material or use it for any profit-making activity or commercial gain

- You may freely distribute the URL identifying the publication in the public portal

If you believe that this document breaches copyright please contact us providing details, and we will remove access to the work immediately and investigate your claim 


\title{
Inventory Centralization Decision Framework for Spare Parts Nicklas Gregersen \& Zaza Nadja Lee Hansen Published in journal: Production Engineering, 2018
}

\begin{abstract}
Within the current literature, there is a lack of a holistic and multidisciplinary approach to managing spare parts and their inventory configuration. This paper addresses this research gap by examining the key contextual factors which influence the degree of inventory centralization and proposes a novel holistic theoretical framework, the Inventory Centralization Decision Framework (ICDF), useful for practitioners. Through an extensive review of inventory management literature, six contextual factors influencing the degree of inventory centralization have been identified. Using the ICDF practitioners can assess the most advantageous inventory configuration of spare parts. The framework is tested on a large global company which, as a result, today actively uses the ICDF; thus showing its practical applicability.
\end{abstract}

Keywords: Centralization, Decentralization, Spare parts, Inventory management, Pooling, Case study research

\section{INTRODUCTION}

Inventory can be described as a "physical stock of goods kept in store to meet the anticipated demand. [...] a usable but idle resource having some economic value." (Vrat, 2014, p. 21). Inventory is often regarded as a necessary evil to meet demand fluctuations; this is substantiated in principles such as lean, where holding inventory is considered a waste (Womack and Jones, 1996), and the agile supply chain, where inventory is held at as few echelons as possible at a time (van Hoek et al., 2001).

Inventory can be divided into four categories - raw materials, work-in-process, finished goods inventory and spare parts - of which this paper focuses on the latter (Hopp and Spearman, 2011). Spare parts are often held in stock for maintenance to use during sudden breakdowns, also known as operational downtime, which can lead to lost revenues, customer dissatisfaction and possible associated claims (e.g. for airlines and public transportation) or public safety hazards (e.g. military settings and power plants) (Driessen et al., 2015; Kennedy et al., 2002). In this paper we define three types of spare parts, inspired by previous research; preventive maintenance, emergency repairs and modificative maintenance (Hopp and Spearman, 2011; Driessen et al., 2015).

The term "inventory pooling" is coined for trans-organizational cooperation where each firm makes their own inventory-sharing decisions (Zhao et al., 2005). Inventory pooling is related to centralized coordination between different firms that share inventory (Rudi et al., 2001; Wong et al., 2006). In this way companies can achieve cost savings on non-core competences through coopetition (Christopher, 2011). While the opportunity for huge cost savings are attractive, it has yet to be a common practice between organizations, as one of the main inhibitors for spare part pooling is the allocation of fair cost between companies (Karsten and Basten, 2014). In this paper, we define pooling as the management of flow of spare parts between local and main warehouses through lateral transshipments.

The concept of inventory centralization dates back to the 1960s (Das and Tyagi, 1997). The main body of research within inventory management of spare parts agree that centralization is the best way to achieve cost savings (Tiacci and Saetta, 2010; Karsten et al., 2012; Braglia and Frosolini, 2013; Cohen et al., 2009; Stoll et al., 2015; Karsten and Basten, 2014). Inventory centralization is in this paper defined as the physical consolidation of local warehouses, procurement and distribution functions to a few (single) main warehouses. Hence centralization does not only refer to the physical consolidation of stock, but also technical and organizational-managerial centralization. It is therefore assumed that spare part inventories can be centralized or decentralized in three different dimensions; physical, technical and organizational-managerial.

Lee and Billington (1993) argue that complete centralized control of materials in a supply chain is neither desirable nor feasible, and Piplani and Fu (2005) state that focus should be moved towards controlling decentralized systems. The extensive body of literature in this area relates to quantitative operations research models or metaheuristic simulations, trying to determine the optimal stock-levels of spare parts, policies for reordering, forecasting methods etc. (Babai et al., 2014; Wingerden et al., 2014; Hahn and Leucht, 2015; Alvarez and van der Heijden, 2014; Ghaddar et al., 2016; Lengu et al., 2014). It is evident there is a lack of qualitative assessment approaches for practitioners to use for determining the optimal inventory configuration of spare part inventories with regards to decentralization or centralization, within their current organizational setup. 
Therefore, the resulting research question (RQ) this paper seeks to address is:

Which factors influence the degree of inventory centralization of a firm's spare parts, and based on the degree of centralization how can the optimal inventory setup configuration be determined?

The RQ is addressed from a contingency theory perspective (Zethaml et al., 1988), using an in-depth case study due to the explorative nature of the research aim.

The aim of this paper is to provide a holistic approach, a framework, to inventory management of spare parts based on contextual factors. This framework is relevant for practitioners whose firm is not manufacturing or selling spare parts, but which does own several production sites and is in need of guidance on managing spare parts.

This paper is structured as follows: Section 2 consists of a literature review which introduces the identified contextual factors; Section 3 provides an outline of the research design; Section 4 presents the case study findings; Section 5 presents the discussion of the findings including details of the implications for theory and practice and Section 6 provides a conclusion, limitations and ideas for future research.

\section{LITERATURE REVIEW}

An exploratory approach has been used to generate literature. The literature search has been conducted for all relevant terms related to centralization and decentralization of spare parts inventory, following the guidelines by Rowley and Slack (2004). The search has been conducted using the library database provided by the Technical University of Denmark, DTU Findit as well as Scopus and Google Scholar. Furthermore, citation pearl growing (Rowley and Slack, 2004) has been used to ensure all relevant literature were identified.

Previous frameworks have mainly focused on inventory control through classification of individual stock keeping units and analyzing demand patterns to determine optimum stock levels, focusing on operational decisions. Recently a comprehensive framework have been proposed by Hu et al. (2018) encompassing both strategic, tactical and operational decisions with regards to spare parts management. Table 1 illustrates some of the recently developed frameworks, but is by no means meant to be comprehensive but are representative in terms of focus area, strengths and weaknesses of the current frameworks.

\begin{tabular}{|l|l|l|}
\hline \multicolumn{1}{|c|}{ References } & \multicolumn{1}{|c|}{ Type of framework } & \multicolumn{1}{c|}{ Strenghts (S) / Weakness (W) } \\
\hline Cavalieri et al., 2008 & $\begin{array}{l}5 \text { phase - Decision-making } \\
\text { framework: coding, classification, } \\
\text { forecast, stock policy,validation }\end{array}$ & $\begin{array}{l}\text { S) Classifies each individual spare } \\
\text { part and a stock policy through } \\
\text { demand forecasting } \\
\text { W) Focused on inventory control of } \\
\text { spare parts }\end{array}$ \\
\hline Hu et al., 2018 & $\begin{array}{l}\text { Framework encompassing also life- } \\
\text { cycle of spare parts into } \\
\text { consideration. Three-layered } \\
\text { framework: objectives of spare part } \\
\text { management, task of spare parts } \\
\text { through lifecycle, OR disciplines for } \\
\text { support spare parts management }\end{array}$ & $\begin{array}{l}\text { S) All-encompassing framework for } \\
\text { management of spare parts through } \\
\text { OR. Adds lifecycle management to } \\
\text { spare parts. } \\
\text { W) No approach for practitioners, } \\
\text { focused on theory and simulations }\end{array}$ \\
\hline Driesen et. al 2015 & $\begin{array}{l}\text { Decision-making framework for } \\
\text { maintenance spare parts }\end{array}$ & $\begin{array}{l}\text { S) Classification of spare parts, } \\
\text { forecasting through demand history } \\
\text { W) Assumes inventory planning is } \\
\text { done centrally for all locations }\end{array}$ \\
\hline
\end{tabular}




\begin{tabular}{|l|l|l|}
\hline & & \\
\hline Xie et al., 2008 & $\begin{array}{l}\text { Optimization framework for optimal } \\
\text { inventory strategy and control } \\
\text { parameters }\end{array}$ & $\begin{array}{l}\text { S) Multi-echelon inventory system } \\
\text { focus. } \\
\text { W) Genetic algorithm not suited for } \\
\text { simply inventory system. }\end{array}$ \\
\hline Zech, 2017 & $\begin{array}{l}\text { Mixed Integer linear program, } \\
\text { integrating: strategic facility choice, } \\
\text { tactical base-stock level setting and } \\
\text { operational sourcing decisions. }\end{array}$ & $\begin{array}{l}\text { S) evaluates physical and virtual } \\
\text { pooling at the same time } \\
\text { W) MILP not very applicable to } \\
\text { practitioners }\end{array}$ \\
\hline
\end{tabular}

Despite the recently more thorough framework provided by $\mathrm{Hu}$ et al. (2018), the main focal point for their contribution is on theory/academia and not practitioners and its practical usability. Hence, there is a need for a dedicated holistic qualitative approach for practitioners to utilize.

\subsection{Scale for Spare Parts Inventory Configuration}

For the scope of this research a complete decentralized inventory configuration is defined as: the production site has own IT-systems, local management and separate inventories (no technical, managerial-organizational or physical storage is shared). While complete centralization is defined as: all production sites have complete transparency of each other's' stock levels through shared IT-systems, central management controlling demand at all locations, and one shared physical storage from where all demand is served. These two archetypes were chosen due to their practical usage and their use in literature (e.g. Tiaccia and Saetta, 2010; Singha et al., 2015; Axsäter, 2005; Tracht et al., 2012; Madadi et al., 2010). The two archetypes should be perceived as two ends of a fully decentralized or centralized setup. Hence the rest of this paper will focus on the degree of inventory centralization for spare parts with these two archetypes as endpoints, and is shown in Figure 1.

Degree of Inventory Centralization

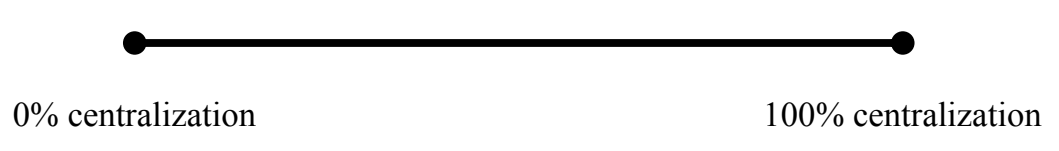

Figure 1: Conceptual scale of the degree of inventory centralization

\subsection{Definition of Contextual Factors}

Contextual factors are in this paper defined as factors which help determine whether a firm should centralize or decentralize its spare parts inventory. The technique applied for uncovering the contextual factors is two-fold; idea generation and screening. Idea generation is done through an extensive literature review, while the screening is done through brainstorming among the authors of the paper and with other researchers in the field. It should be noted that a holistic view of inventory management of spare parts is pursued. The influencing factors related to individual stock keeping units (SKU) have not been taken into consideration, as it is assumed the practitioner will possess the capability to determine whether the spare parts are stored at centralized or decentralized sites.

There are two main approaches to analyzing organizational setups within operations management, namely the resource based view and the contingency approach. The resource based view states the organizational strategy should follow the organizational structure, hence the organizational structure is perceived as a core competence (Pertusa-Ortega et al., 2010; Barney et al., 2001), while the contingency approach sees strategy as a contingent factor. The contingency approach (Chandler, 1962) is used while identifying the contextual factors which influence the optimal degree of inventory centralization. The contingency approach states that the organizational structure must follow the organizational strategy (Mintzberg, 1979; Chandler, 1962). Since manufacturing firms rarely have inventory management of spare parts as a core competence, the contingency approach is chosen in favor of a resource based view. 
The contingency approach is used in coherence with a deductive case study, as both seek to go from theory to practice (Yin, 1994). The contingent factors represent the firm's situation in an external business environment (Zeithaml et al., 1988), and the optimal configuration of spare parts inventories is based on the identified contextual factors.

Two types of contextual factors have been identified, namely strategic and operational. The operational factors are defined as production site specific factors, while strategic factors relate to governing firm goals. The differentiation is made as the strategic factors are the same for all the storage locations within an organization, while the operational factors must be compared for all storage locations. This is to identify whether it would be feasible to centralize individual warehouses, even though the general strategic factors might point towards decentralization. Identified factors such as Commonality of Spare parts, is an operational factor, and the commonality between all warehouses should be individually assessed, to identify whether some of the warehouses have a high degree of commonality while others might not.

\subsection{Identified Contextual Factors}

Through an extensive literature alongside idea generation and screening phase, six contextual factors have been identified. The identified contextual factors are presented below and categorized as either being strategic or operational, and summarized in Table 1.

\section{Strategic factor 1: Contribution of spare parts management}

According to Kennedy et al. (2002), one of the main issues in management of spare parts is to determine the goal of spare parts within a firm either to reduce cost or increase availability. Inventory management of spare parts can contribute to a firm's competitive advantage in at least two ways. Efficient management of spare parts result in lower invested capital and minimizes total supply chain costs, enabling the firm to a potential cost advantage (Wagner et al., 2012). This can be seen as a cost-leadership strategy (Porter, 1980). Conversely, inventory management of spare parts can help to achieve competitive advantage through a responsive strategy, in markets (medical, fast-moving consumer goods, etc.) where production downtime is significant and critical towards delivery performance.

\section{Strategic factor 2: System capability}

This factor relates to the technical capabilities of the firm. The technological aspect of the firms' inventory setup is used to assess if there is a system in place for capturing and analyzing inventory data across different warehouses and production sites within the firm. The need to address this as a contextual factor was identified during the case study research together with the case company.

\section{Strategic factor 3: Risk patterns}

The contextual factor of risk patterns relates to the demand and supply pattern between the production sites and the risk willingness of the firm. Demand patterns and supply disruptions can be either deterministic or stochastic. A decentralized inventory setup is optimal when stochastic supply disruptions and deterministic demand patterns are present (Schmitt et al., 2014), as the cost-variance is lowered for a decentralized setup in a stochastic supply environment and the expected cost is equal for both a centralized and decentralized setup under deterministic demand. Oppositely, a centralized inventory setup is proven optimal under deterministic supply disruptions and stochastic demand patterns (Schmitt et al., 2014), due to a lower expected cost by the centralized setup and equal cost for a centralized and decentralized setup of the cost-variance. Schmitt et al. (2014) further examined the optimal inventory configuration based on a stochastic demand pattern and stochastic supply disruption environment, and showed that the optimal choice of centralization or decentralization was based on the risk willingness of the firm.

\section{Operational factor 1: Cost of downtime}

One of the main considerations practitioners face when determining the optimal inventory configuration of spare parts, is the cost of downtime. Spare parts are often held decentralized at production sites, to avoid extensive periods of downtime. If the cost of downtime is considered high, the greater the benefit is of a decentralized inventory configuration (Wang and Yue, 2015). The decentralized inventory configuration ensures that there is always a spare part in stock and production only faces downtime if several machines require the same spare part while a part is retrieved. If the cost of downtime is low compared to the cost of carrying excessive stock with no stock turn, a centralized inventory configuration provides the most cost efficient system.

To avoid assumptions of which factors a firm should have as part of their downtime cost, the authors propose the following formula (see equation 1) to estimate a firms' Contextual Cost of Downtime (CCD). The CCD is to be used when estimating the cost of downtime. 


$$
C C D=\frac{\text { Firms hourly cost of downtime }}{\text { Firms hourly revenue }} * 100
$$

\section{Operational factor 2: Inventory holding cost}

The inventory holding cost is an important factor when considering the degree of centralization of spare parts inventory. Wanke and Saliby (2009) state that "[...] high holding cost items should be kept centralized, and, the smaller is the holding cost, the higher is the degree of inventory decentralization.". Furthermore, Wang and Yue (2015) summarized that the higher the holding cost, the more beneficial it is to move towards a higher degree of centralization, as the holding cost per unit decreases, a lesser degree of centralization should be sought.

The true inventory holding cost is hard to estimate as manual warehouse systems often contain both semi-hidden and hidden holding costs (Azzi et al, 2014). Richardson (1995) presented a cost-to-carry matrix which estimated the total inventory holding cost as ranging between $25 \%-55 \%$ of the average annual inventory value. This is in coherence with the range of $20 \%-50 \%$ of inventory value as presented by Schonberger and Knod (1997) and Pyke and Cohen (1994). Azzi et al. (2014) split the inventory holding cost into several sub-categories and through an empirical study confirmed the general rule of thumb of $25 \%$ of inventory value being the annual inventory holding cost.

To avoid ambiguity the authors, propose a Contextual Inventory Holding Cost (CIHC) formula (see equation 2) to be used when assessing a firms' inventory holding cost.

$$
\text { CICH }=\left(\frac{\text { Total annual cost of spare parts inventory }}{\text { Total value of spare parts on stock }}\right) * 100
$$

\section{Operational factor 3: Commonality of spare parts}

The contextual factor commonality of spare parts relates to the commonality of spare parts across the centralized organizations. The aviation industry and military has proven successful in pooling spare parts, due to a high level of commonality on component level, despite having different models and owned by different companies (Karsten and Basten, 2014). Kranenburg and Van Houtum (2007) showed that the savings obtained by sharing stock are significantly dependent by the level of commonality, especially for the high-value SKUs. Even intra-organizational commonality of production equipment components can reduce down time significantly (Seidel, 1983). To achieve savings by centralizing the spare parts inventory a significant number of components must be used interchangeably between the cooperating manufacturers.

The level of commonality is in this paper defined as; the intra-organizational level of component commonality between all individual factories, measured as percentage of common components between plants. A high level of commonality points towards centralization, while a low level of commonality points towards decentralization.

For the remainder of this paper, the contextual factors will be abbreviated SFx for Strategic contextual Factor number $\mathrm{x}$ ( $x$ being the number of the strategic factor as presented in this section). While Operational contextual Factors will be abbreviated OFx, following the same logic as SFx. 
Table 1: Contextual factors

\begin{tabular}{|c|c|c|c|c|}
\hline \multirow[b]{2}{*}{$\begin{array}{l}\text { Contextual } \\
\text { Factor }\end{array}$} & \multirow[b]{2}{*}{$\begin{array}{c}\text { Key } \\
\text { references }\end{array}$} & Input & \multicolumn{2}{|c|}{ Output } \\
\hline & & Impact & Decentralization & Centralization \\
\hline SF1 & $\begin{array}{l}\text { Kennedy et } \\
\text { al. (2002) } \\
\text { Wagner et } \\
\text { al. (2012) } \\
\text { Porter } \\
(1980)\end{array}$ & $\begin{array}{l}\text { Inventory management of spare parts can contribute to a firm's competitive } \\
\text { advantage in at least two ways. } \\
\text { - Efficient management of spare parts (cost-leadership) } \\
\circ \text { Lower invested capital } \\
\circ \text { Minimized total supply chain costs. } \\
\text { - Effective management of spare parts (responsive strategy) } \\
\circ \quad \text { Increased delivery performance } \\
\circ \quad \text { Reduced production downtime }\end{array}$ & $\begin{array}{l}\text { Effective management of spare parts } \\
\text { (responsive strategy) } \\
\text { - Stock will be on hand near } \\
\text { production } \\
\text { - Risk of overstocking }\end{array}$ & $\begin{array}{l}\text { Efficient management of spare parts (cost- } \\
\text { leadership strategy) } \\
\text { - Reduced complexity } \\
\text { - Reduced invested capital }\end{array}$ \\
\hline SF2 & $\begin{array}{l}\text { Chandler } \\
(1962) \\
\text { Axsäter } \\
(2005) \\
\text { Singha et al. } \\
(2015) \\
\text { Wagner et } \\
\text { al. (2012) }\end{array}$ & $\begin{array}{c}\text { The technical capability of the firm impacts: } \\
\text { - Transparency } \\
\text { - } \quad \text { Sarehouse alignment } \\
\text { Stock level decisions }\end{array}$ & $\begin{array}{l}\text { If no system is available to support the supply } \\
\text { chain transparency. } \\
\text { - High cost associated with procuring } \\
\text { and implementing a system that can } \\
\text { handle the required information }\end{array}$ & $\begin{array}{l}\text { If a system is in place, the technological } \\
\text { aspect points towards a centralized } \\
\text { configuration. }\end{array}$ \\
\hline SF3 & $\begin{array}{l}\text { Schmitt et } \\
\text { al. }(2014)\end{array}$ & $\begin{array}{l}\text { The risk willingness of the firm impacts the stocking policies and inventory } \\
\text { configuration of the firm. } \\
\text { - A risk-averse company will be more willing to stock less and } \\
\text { centralize more. } \\
\text { - A risk-neutral company will be keener on stocking SKUs on } \\
\text { warehouses close to production sites or at the production site itself. }\end{array}$ & $\begin{array}{l}\text { A decentralized inventory setup is optimal } \\
\text { when; } \\
\text { - stochastic supply disruptions and } \\
\text { deterministic demand patterns are } \\
\text { present } \\
\text { - Risk-averse nature }\end{array}$ & $\begin{array}{l}\text { A centralized inventory setup is proven } \\
\text { optimal under; } \\
\text { - Deterministic supply disruptions } \\
\text { and stochastic demand patterns } \\
\text { - Risk-neutral nature }\end{array}$ \\
\hline OF1 & $\begin{array}{l}\text { Wang and } \\
\text { Yue (2015); } \\
\text { Singha et al. } \\
(2015) ; \\
\text { Patterson } \\
(2002)\end{array}$ & $\begin{array}{l}\text { The decentralized inventory configuration can ensure that a spare part is } \\
\text { instantaneously available and production only faces downtime if several } \\
\text { machines require the same spare part while a new is retrieved. Though, if the } \\
\text { cost of downtime is low compared to the cost of carrying excess stock with no } \\
\text { stock turn, a centralized inventory configuration provides the most cost } \\
\text { efficient system. }\end{array}$ & $\begin{array}{l}\text { If the cost of downtime is high a decentralized } \\
\text { inventory configuration is preferred }\end{array}$ & $\begin{array}{l}\text { If the cost of downtime is low, due to not } \\
\text { running full capacity production or similar, a } \\
\text { centralized inventory configuration is } \\
\text { preferred. }\end{array}$ \\
\hline OF2 & $\begin{array}{l}\text { Wang and } \\
\text { Yue }(2015) \\
\text { Wanke and } \\
\text { Saliby } \\
(2009)\end{array}$ & $\begin{array}{l}\text { The general rule of thumb of } 25 \% \text { inventory holding cost, is used to } \\
\text { distinguish between a high level or low level of inventory holding cost. }\end{array}$ & $\begin{array}{l}\text { For low inventory holding costs the } \\
\text { decentralized inventory configuration should } \\
\text { be sought. }\end{array}$ & $\begin{array}{l}\text { For high inventory holding costs the } \\
\text { centralized inventory configuration should be } \\
\text { pursued. }\end{array}$ \\
\hline
\end{tabular}

Page 6 of 17 


\begin{tabular}{|c|c|c|c|c|}
\hline & $\begin{array}{l}\text { Azzi et al. } \\
(2014) \text {, } \\
\text { Richardsion } \\
(1995) \\
\text { Schonberger } \\
\text { and Knod } \\
(1997)\end{array}$ & & & \\
\hline OF3 & $\begin{array}{l}\text { Karsten and } \\
\text { Basten } \\
(2014) \\
\text { Kranenburg } \\
\text { and van } \\
\text { Houtum } \\
(2007) \\
\text { Seidel } \\
(1983)\end{array}$ & $\begin{array}{l}\text { High level of commonality has highest impact, if the components with } \\
\text { commonality are of high value. } \\
\text { - Sharing of stock generate savings } \\
\text { - Can reduce downtime significantly } \\
\text { Low level of commonality or only commonality between low value SKUs } \\
\text { - No benefit in moving towards centralization }\end{array}$ & $\begin{array}{l}\text { A low level of commonality points towards } \\
\text { decentralization. }\end{array}$ & $\begin{array}{l}\text { A high level of commonality points towards } \\
\text { centralization }\end{array}$ \\
\hline
\end{tabular}




\subsection{Framework for centralization degree of spare parts inventory}

Through the literature review it is proposed that all six contextual factors influence the level of decentralization or centralization of the inventory configuration. The authors propose the ICDF to determine a firms' degree of inventory centralization of spare parts; first using a qualitative and then a quantitative approach.

To determine the degree of inventory centralization and hence the firms' placement on Figure 1, a quantitative analysis is applied. The quantitative approach is a modified version of the one presented by Hansen et al. (2017). The different contextual factors are weighted according to their perceived importance using a pair-wisecomparison method. In Table 2, the row and column labels, abbreviates the contextual factors as per Table 1. The factors in the row are compared with the factors in each column. If the factor in the row is perceived to be more important than the one in the column, it is assigned the value of ' 1 ' while if less important the value is set to ' 0 '. If the two factors are equally important the value is set to ' 0.5 '. Once all factors have been evaluated each row total value is summarized in the column Absolute weight and the Relative weight is derived.

Table 2: Quantitative analysis

\begin{tabular}{|l|l|l|l|l|l|l|l|l|l|}
\hline & SF1 & SF2 & SF3 & OF1 & OF2 & OF3 & $\begin{array}{l}\text { Decentralization } \\
\text { or centralization }\end{array}$ & $\begin{array}{l}\text { Absolute } \\
\text { weight }\end{array}$ & $\begin{array}{l}\text { Relative } \\
\text { weight }\end{array}$ \\
\hline SF1 & & & & & & & & & \\
\hline SF2 & & & & & & & & & \\
\hline SF3 & & & & & & & & & \\
\hline OF1 & & & & & & & & \\
\hline OF2 & & & & & & & & \\
\hline OF3 & & & & & & & & & \\
\hline
\end{tabular}

The weights for the different contextual factors should be determined by procurement managers, maintenance managers, and other key stakeholders. The weights should reflect the strategic priorities of the firm concerning spare parts management. Based on the qualitative analysis of the contextual factors, each factor should ideally point towards either centralization or decentralization. If the contextual factor points towards decentralization it is, for the purpose of the quantitative analysis, assigned a ' -1 ', while pointing towards centralization it is assigned a ' +1 '. Contextual factors with an ambiguous result are assigned a ' 0 '. This result is put into the column Decentralization or centralization in Table 2 . The degree of inventory centralization is then calculated based on the formula presented below;

$$
\begin{aligned}
& \text { Degree of Inventory Centralization } \\
& =\left(\frac{\left(\sum(\text { relative weight }) *(\text { Decentralization or Centralization })\right)+1}{2}\right) * 100 \%
\end{aligned}
$$

The result of this calculation is a number between 0 and $100 \%$, where $0 \%$ indicates that complete decentralization is the optimal inventory configuration while $100 \%$ indicates that complete centralization is the optimal configuration. The ICDF will be validated and further detailed using a case study.

\section{CASE STUDY RESEARCH DESIGN}

A case study approach was selected due to the explorative nature of the research (Yin, 1984; 1994). To generate findings the cases, pages and time spent is not essential, but a clear understanding of the context and capability of drawing findings is crucial (Hilmala et al., 2005; Yin, 1984; 1994; Dyer and Wilkins, 1991; Meredith, 1998; Hill, Nicholson and Wash, 1999). A single case study method was chosen as it has the advantage of allowing greater depth, but the primary disadvantage is the lack of generalizability of the findings (Voss et al., 2002; Kuhn, 1996; Zainal, 2007). However, generalization is not a goal of this study as this research is explorative and seeks to create a proof of concept for the proposed ICDF through a holistic application of the contextual factors derived from the literature review.

The case analysis is evaluated on the four criteria put forth by Hilmala et al. (2005) for a successful descriptive case study; relevant to practitioners, theoretical connections, usability in practice and theoretical novelty value. A descriptive deductive method was chosen for the case analysis as it draws on theory and logical findings from literature to answer the presented research question (Hilmala et al, 2005) and to test the developed ICDF (Zainal, 2007). 


\subsection{Case Firm}

The case firm is a European insulation manufacturer. The firm has a network of 28 operational companies worldwide, with sixteen in Europe. The firm is called Thermo A/S for confidentiality reasons. The focus of this case study is on the sixteen European operational companies, and whether a centralized or decentralized spare parts inventory configuration should be pursued. Thermo A/S serves both the business-to-business as well as the business-to-customer segment. Each operational company has gradually been acquired and erected as Thermo $\mathrm{A} / \mathrm{S}$ has gained larger market shares.

\subsection{Data Collection - Interviews and Internal Survey}

The case analysis is based on information from internal documents and semi-structured interviews with key employees throughout the organization. Four people from Group Procurement were interviewed and two maintenance managers. Group Procurement is responsible for managing stock level and procurement policies at the case firm. Each interview lasted approximately an hour and key points were noted during each interview and afterwards cleansed and send for approval of the interviewee to avoid misinterpretations. Then the interviews were coded and analyzed. Interviews are the primary source of information when analyzing a firm's AS-IS situation, it is also the most efficient way to gain knowledge of a firm's current situation, as it is rarely documented. The interviews are based on Kvale's (1997) two arch roles: the traveler and the miner. The roles are applied sequentially. The traveler uses a semi-structured interview which allows for free associations, whereas the miner aims to gain specific data and detailed knowledge from the interviewee through a structured interview. Kvale's (1997) two arch roles also correspond to the funnel strategy introduced by Mandel (1974).

To ensure a correct assessment of the overall AS-IS situation and thus validate the interview results a quantitative survey was conducted within the case firm to get consistent data input from maintenance managers across Europe on plant level. The quantitative survey was used to identify current practices among different operational companies within the case firm and to gather specific numbers related to the spare parts inventory at the given site. The survey follows an inductive approach and was sent to seven operational companies, selected by the Category Director of Maintenance, Repair and Operational supplies (MRO). The chosen operational companies are geographically representative for the sixteen European plants owned by the case company and will represent the European inventory configuration of the case company. Maintenance managers from all seven operational companies answered the survey. The survey consisted of six parts, with a total of twelve questions.

\subsubsection{Validity of collected data}

The condensation principle is used for the data collected through interviews (Thomas, 2006; Malterud, 2012). The condensation principle builds on the principle that optimal output from interviews can be gained through condensation of key points rather than transcribing entire interviews. The condensation principle revolves around extracting only the essential points in the form of notes during the interview. Next step is then to clean the notes and validate the remaining points with the interviewee. This ensures that no interviewee is misinterpreted and that they get a chance to further elaborate. To ensure reliable data, the interview data is coded by two independent persons (Thomas, 2006). This ensures rigidity and transparency of the interview. Hence, care is taken to avoid some of the problems normally associated with a case study based methodology, e.g. the lack of rigidity (Meredith, 1998).

The research relies on multiple data sources within the case firm, allowing the use of triangulation to find converging themes and lines of inquiry (Voss et al., 2002). Finally, the results from the case study were presented to managers and employees in the case firm to further validate the results.

\section{CASE STUDY FINDINGS}

This section contains the analysis of the case firm based on the six identified contextual factors to determine the optimal degree of inventory centralization within Thermo A/S.

\subsection{Qualitative analysis}

The analysis of the six contextual factors for the case firm has been comprised in Table 3 for easy comparison of the output of the AS-IS situation and contextual situation. The operational contextual factor of Cost of Downtime has not been evaluated for the case firm, as it was not possible to retrieve any figures on this factor. Furthermore, the operational contextual factor Commonality of spare parts has been applied on a large-scale comparison instead of the proposed individual comparison between all warehouses. Due to the fact of available data at the time. 


\begin{tabular}{|c|c|c|c|}
\hline \multirow[t]{2}{*}{ Contextual Factor } & \multirow[t]{2}{*}{ Case Analysis } & \multicolumn{2}{|c|}{ Centralization or Decentralization } \\
\hline & & AS-IS & Contextual \\
\hline SF2 & $\begin{array}{l}\text { The managerial as well as technical capabilities are at Thermo A/S present, though not utilized. Thermo } \mathrm{A} / \mathrm{S} \text { has a } \\
\text { global ERP system able to encompass the data from all operational companies. Currently the ERP system is used } \\
\text { incoherently, and does not offer full transparency and management capability. Though, from a technical point of } \\
\text { view the ability to achieve transparency and managing it from a centralized point is present. Furthermore, the lack } \\
\text { of a centralized master data department makes the management of coherent data management difficult. }\end{array}$ & Decentralization & Centralization \\
\hline SF3 & $\begin{array}{l}\text { Thermo A/S is risk averse in relation to management of spare parts; partly because the spare parts should figure in } \\
\text { a responsive supply chain and because there is a general lack of risk considerations when procuring/stocking spare } \\
\text { parts. From an interview with a local MRO manager the following example was given: Newly bought equipment } \\
\text { contained several different motors, which could be supplied from the manufacturer within } 48 \text { hours in case of a } \\
\text { breakdown. Even though this information was relayed, it was decided to procure one of each type of motor, which } \\
\text { could be received with short notice, leading to a huge investment of spare parts. }\end{array}$ & Decentralization & Decentralization \\
\hline OF3 & $\begin{array}{l}\text { Approximately } 5000 \text { SKUs are utilized across the operational companies which corresponds to approximately } 5 \% \\
\text { of the total number of spare parts; leading to a low level of shared components. The current situation of Thermo } \\
\text { A/S is highly decentralized. Within the context of Thermo A/S there is a huge potential for harmonization of spare } \\
\text { parts and hence increasing commonality at the warehouses. This is based on the fact that all operational companies } \\
\text { within Thermo A/S, basically produce the same product. }\end{array}$ & Decentralization & Centralization \\
\hline
\end{tabular}

Page 10 of 17 


\subsection{Quantitative Analysis}

For the quantitative analysis, a process specialist with extended experience within inventory management in the Group Procurement division of Thermo A/S, have assessed the importance of the different contextual factors for Thermo A/S. The results were hereafter shown to the key stakeholders at the case company to ensure validity of the assessment of the firm specialist's results. Table 6 summarizes the pair-wise-comparison, the relative weight of each factor and how they influence on centralization or decentralization (from the qualitative analysis).

Table 4: Quantitative analysis

\begin{tabular}{|l|c|c|c|c|c|c|c|c|c|c|}
\hline & \multirow{2}{*}{ SF1 } & \multirow{2}{*}{ SF2 } & \multirow{2}{*}{ SF3 } & \multirow{2}{*}{ OF1 } & \multirow{2}{*}{ OF2 } & \multirow{2}{*}{ OF3 } & \multicolumn{2}{|c|}{$\begin{array}{l}\text { Decentralization or } \\
\text { centralization }\end{array}$} & $\begin{array}{l}\text { Absolute } \\
\text { weight }\end{array}$ & $\begin{array}{l}\text { Relative } \\
\text { weight }\end{array}$ \\
\cline { 8 - 9 } & & & & & & & AS-IS & Contextual & & \\
\hline SF1 & & 0 & 0 & 0 & 0 & 0 & -1 & -1 & 0 & $0 \%$ \\
\hline SF2 & 1 & & 0 & 0,5 & 0,5 & 0 & -1 & 1 & 2 & $18 \%$ \\
\hline OF1 & 1 & 1 & & 0,5 & 1 & 0,5 & & & 4 & \\
\hline OF2 & 1 & 0,5 & 0,5 & & 0,5 & 0,5 & -1 & -1 & 3 & $27 \%$ \\
\hline OF3 & 1 & 1 & 0,5 & 0,5 & & 0 & -1 & -1 & 2 & $18 \%$ \\
\hline
\end{tabular}

The contextual factors cost of downtime, commonality of spare parts and inventory holding cost are among the most important contextual factors. The relative weight is used to calculate the degree of inventory centralization for both the AS-IS situation and the contextual analysis of Thermo A/S. The AS-IS analysis of Thermo A/S shows a highly decentralized inventory configuration. The quantitative model yields $0 \%$. The AS-IS degree of inventory centralization is visualized on the conceptual scale in Figure 2.

Current position of Thermo A/S

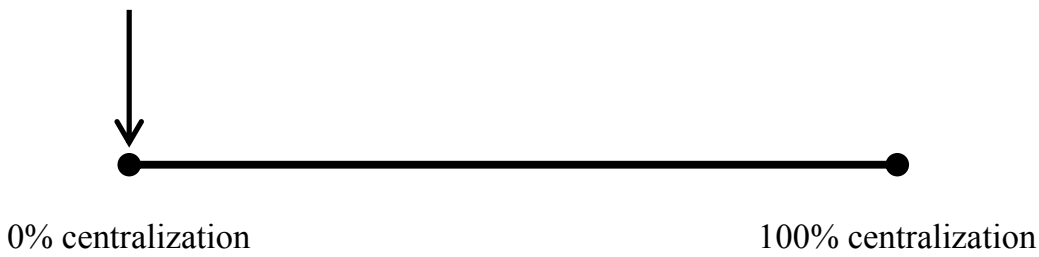

Figure 2: AS-IS situation visualized

For the contextual analysis, Thermo A/S, points towards centralization in both System capabilities and Commonality of spare parts. This yields 54\% degree of inventory centralization. The degree of inventory centralization for the contextual analysis is visualized in Figure 3.

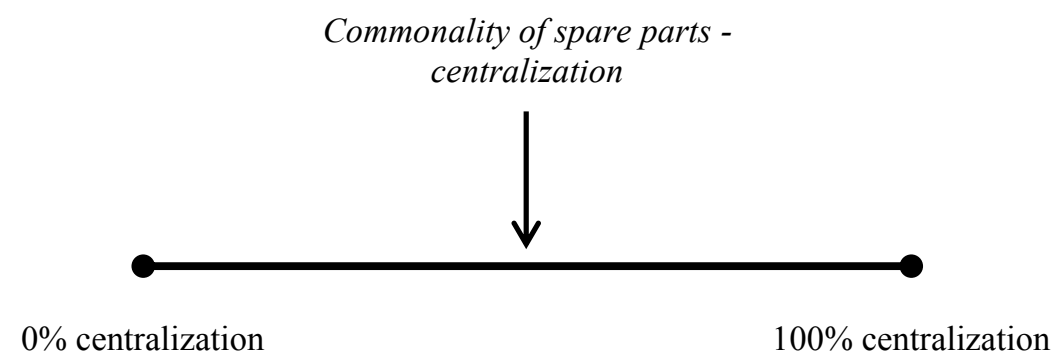

Figure 3: Qualitative analysis visualized

The difference between the AS-IS situation and the contextual analysis is the utilization of the IT-system which is in place at Thermo $\mathrm{A} / \mathrm{S}$, and the contextual potential for increasing the commonality of the spare part stocks. Currently the ERP system is by far underutilized and no common process is in place for managing spare parts; hence leading to a proliferation of spare parts.

\subsection{Improvement suggestions for Thermo $\mathrm{A} / \mathrm{S}$}

Based on the perceived importance of each contextual factor for Thermo A/S, the most important factor is the Commonality of spare parts. Even though this factor from a contextual point of view points towards centralization, a lot of work is required to achieve their contextual potential within this factor. The contextual factors System capabilities also pointed towards centralization for Thermo A/S, and would be the best place for them to start, if they wish to pursue a more centralized inventory configuration. 
The second step for Thermo A/S is to reduce the invested capital to clean stock of obsolete spare parts. Furthermore, reduction of redundant spare parts should be pursued and a general guideline for codification of spare parts should be set in place to avoid further SKU proliferation.

The second most important factor for Thermo A/S was the Inventory Holding Cost. The inventory holding cost presented during the case study was a fixed value for indoor and outdoor let based on square-meter-usage. For Thermo A/S, it would be beneficial to uncover the actual inventory holding cost within their organization, as the authors can see a lot of cost components not factored into Thermo A/S' current calculation. Uncovering the actual holding cost might even swing the context towards centralization if the cost is shown to be considerable.

The improvement suggestions for Thermo A/S are in Table 5 summarized.

\section{Table 5: Summary of Improvement suggestions}

\begin{tabular}{|c|c|c|}
\hline Technical improvements & Physical improvements & Organizational improvements \\
\hline $\begin{array}{l}\text { Thermo A/S, should start their } \\
\text { process of moving towards a more } \\
\text { centralized setup, with ensuring } \\
\text { the technological baseline is in } \\
\text { place. Thermo A/S, should clean } \\
\text { up their master data in their ERP } \\
\text { (Enterprise Resource Planning) } \\
\text { system. Furthermore, standardized } \\
\text { processes for managing the data } \\
\text { and working in the ERP system } \\
\text { should be set in place. This will } \\
\text { increase the reliability of the data } \\
\text { and improve the transparency } \\
\text { throughout the supply chain. } \\
\text { This is a prerequisite before any } \\
\text { actions can be taken towards } \\
\text { sharing stock } \\
\text { warehouses. }\end{array}$ & $\begin{array}{l}\text { Thermo A/S, should clean their } \\
\text { warehouse stocks, and try to } \\
\text { identify high-value spare parts } \\
\text { which can be utilized at several } \\
\text { production sites and consolidate } \\
\text { the stock of these at one } \\
\text { warehouse. This action is related } \\
\text { to the classification process as not } \\
\text { all items can be centralized due to } \\
\text { their criticality. } \\
\text { It should be considered whether } \\
\text { physical consolidation is } \\
\text { appropriate or if a virtual } \\
\text { warehouse is more suited, than the } \\
\text { costs associated with physical } \\
\text { moving of spare parts. }\end{array}$ & $\begin{array}{l}\text { Even though the contextual factor } \\
\text { of Strategic contribution of spare } \\
\text { parts management did not receive } \\
\text { much attention. Thermo A/S, } \\
\text { should consider their current short } \\
\text { delivery time and very responsive } \\
\text { strategy towards customers. } \\
\text { Taking into consideration the } \\
\text { product and market they are } \\
\text { serving is the building industry, } \\
\text { not a market with high margins } \\
\text { based on being responsive, were a } \\
\text { cost-leadership approach is more } \\
\text { suitable. }\end{array}$ \\
\hline
\end{tabular}

\section{DISCUSSION}

\subsection{Contribution to Theory}

The key contribution to theory is the identification of a set of contextual factors to determine the appropriate degree of inventory centralization. The use of a qualitative methodology presents a novel approach to inventory management of spare parts. This paper contributes to the body of spare parts inventory management in several ways;

- Identification of the key contextual factors determining the optimal degree of inventory centralization

- A quantitative analysis to determine the current and optimal degree of inventory centralization for spare parts

- Development of ICDF useful for practitioners for assessing their inventory configuration The identified contextual factors are further discussed in this section.

\subsubsection{Contextual factors}

The ICDF takes a holistic view on inventory configuration with regards to spare parts, and further provides novel ways of estimating the cost of downtime and inventory holding cost. The two approaches are centered on being contextual, and hence are directly compared with the firms' current context, and not based on rule of thumb or similar provided by the literature. The primary difference from general research is that the ICDF does not try to identify the factors which influence the true inventory holding cost or cost of downtime within a firm, as these are assumed to be irrelevant when looking only at the firm's context. Hence to find the optimal inventory configuration; the ICDF simply considers the firm's own estimation and assessment of its costs. The disadvantage of this is that if the inventory holding and downtime cost within the context are erroneous, the 
decision basis might also be erroneous. It is therefore worth noting that for the ICDF to work optimally, the firm should be clear in their costs and how they are evaluated within their firm.

One of the main challenges of the ICDF is the contextual approach itself. As all factors are dependent on the context in which the firm operates; the contextual factor commonality of spare parts plays a huge role in the decision whether to centralize or decentralize spare parts inventory. To unravel the true conditions of the context, a resource-based view approach should be applied before using this contextual framework to minimize the redundancy of spare parts and ensure substitution. Hence after every major policy change, the firm should reevaluate their position with regards to the ICDF, to see if it warrants a change in their current inventory configuration.

\subsection{Contribution to Practice}

This paper provides a novel framework, the ICDF, which integrates six identified contextual factors to help practitioners identify the optimal degree of inventory centralization. The ICDF provides a holistic view of the inventory management of spare parts, and is not limited to a single variable or SKU level analysis. The ICDF provides practitioners with a qualitative approach to assessing the firms' current configuration as well as the optimal configuration based on the actual context. Furthermore, the ICDF consists of a quantitative approach which turns the qualitative analysis into a percentage inventory centralization ranging from $0 \%$ to $100 \%$. To utilize the ICDF, the authors propose the following six steps:

Step 1: Conduct the qualitative analysis by interviews

Step 2: Conduct the quantitative analysis using key stakeholders, to determine the importance of each contextual factor

Step 3: Determine the current and optimal degree of inventory centralization using the gathered data and the importance score for each contextual

Step 4: Compare the current degree of inventory centralization with the optimal degree of inventory centralization

Step 5: Directions and suggestions should be set for improving the degree of inventory centralization, to match the firms' context

Step 6: Evaluate suggestions using cost-benefit analysis

The steps are further explained along with the influence of the contextual factors depicted in Figure 4, which encompass the ICDF. 


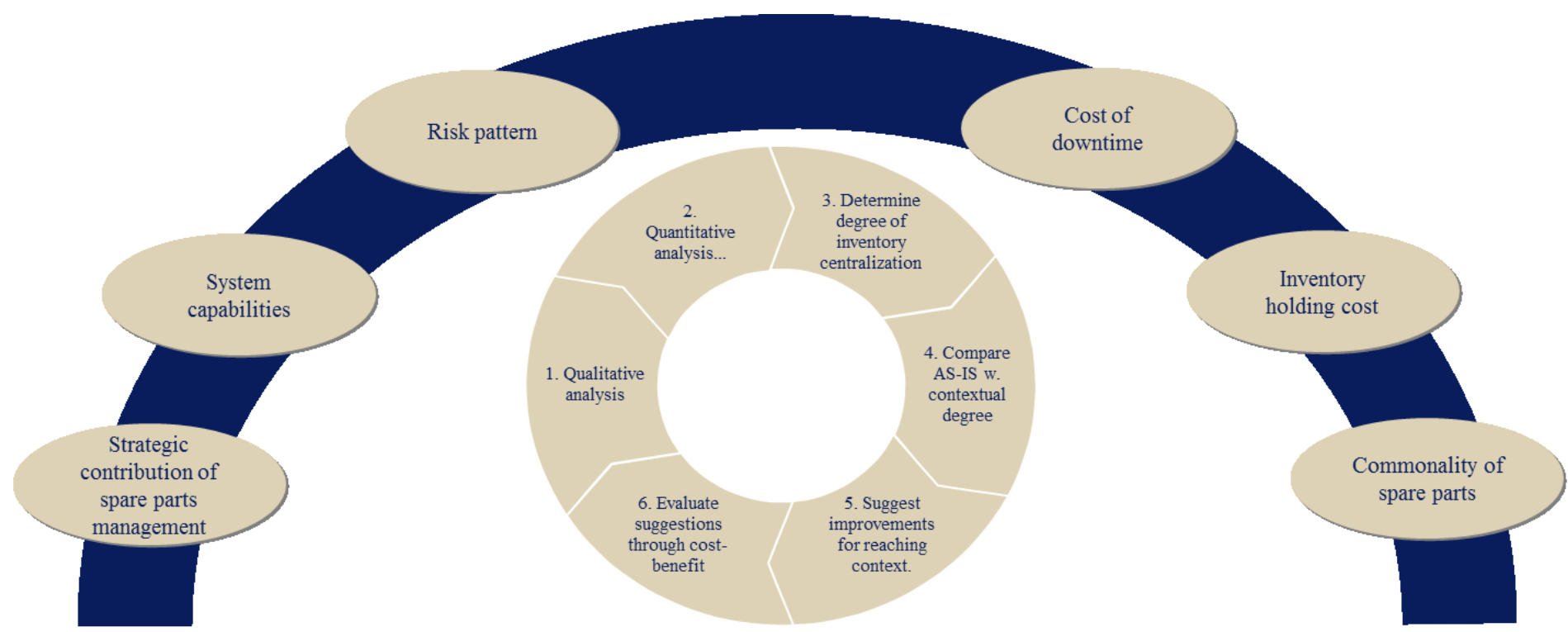

Degree of Inventory Centralization

Conduct the qualitative analysis of the firm

\section{- Interviews}

Internal documents

Conduct the quantitative analysi

- Gather key stakeholders

Determine importance of each contextual

factor using the pair-wise-comparison matrix

Determine the current and contextual degree of

inventory centralization

- Using collected data and the importance score of each contextual factor

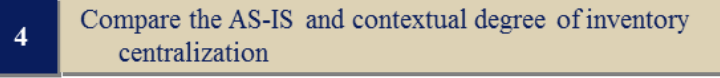

- Utilizing the conceptual scale for the degree of inventory centralization
Set direction and suggestions for improvements

GAP-analysis of AS-IS situation and contextual situation

Generate tasks and ideas for reaching the contextual degree of inventory centralization

Evaluate suggestions

- Cost-benefit analysis of generated suggestions Implement economic feasible solutions

Figure 4: Inventory Centralization Decision Framework (ICDF) 
Based on the result of the ICDF, practitioners should aim to either centralize or decentralize their spare parts inventory configuration. The most apparent to pursue when discussing inventory centralization is physical consolidation of stock. As mentioned, centralization can be considered on physical, technical and managerialorganizational level. This is also seen in practice as shown in Axsäter et al. (2013), where Volvo Parts have a physically decentralized setup with a highly centralized technical and managerial-organizational configuration. Hence improvements can be made within these three areas to achieve the optimal degree of inventory centralization. The authors propose that the first step in centralization should be within the technical area as transparency throughout the supply chain is the first step towards sharing of spare parts. Secondly, managerialorganizational improvements should be sought, as this avoids SKU proliferation and ensures a common codification process as this will be handled centrally. Lastly, physical improvements should be considered as merging stock and consolidation of warehouses are major steps to take.

\section{CONCLUSION}

This paper address the research question: "Which factors influence the degree of inventory centralization of a firm's spare parts, and how can the optimal inventory setup be configured based on this centralization degree?"

This was done by identifying six contextual factors, which all contribute to the degree of inventory centralization for spare parts. A conceptual scale was developed encompassing a continuum of $0 \%$ to $100 \%$ of centralization. Based on the identified six contextual factors and the developed conceptual scale, the ICDF has further been developed, to help practitioners determine the most beneficial inventory configure for spare parts within their firm. The ICDF is a novel approach to identifying optimal inventory configurations, as the current body of literature within inventory management mainly revolves around optimizing the configuration based on several assumptions through mathematical models, which is rarely used in practice. The ICDF is readily applicable and can be used by all practitioners.

The ICDF was tested using a case study of the firm Thermo A/S. The results of the case study were unveiled during a workshop for the Group Procurement Management Team at Thermo A/S. The management team approved the usability of the ICDF as well as the results of the case analysis, and is currently moving forward with actively using the ICDF in their decision process regarding spare parts inventory. The case firm is currently harmonizing the ERP system utilization and increasing transparency throughout all factories, as per the conclusion of the qualitative analysis aspect of the ICDF which showed that the best place to start, was the factor System capabilities to increase the degree of inventory centralization. Furthermore, in coherence with this harmonization project, Thermo A/S, has started to classify all their spare parts based on criticality. Thus, the case study has shown proof of concept for the ICDF and shown practical usability of it in one of the world's market leaders within the insulation industry.

The main limitation of the provided case study is the lack of data regarding cost of downtime, and the fact that the operational factors have not been widely applied to each factory, but have been treated holistically. For future research and for the best application of the ICDF practitioners should apply the operational factors to each factory and compare them against each other to discover factory similarities to make informed decisions regarding physical consolidation of stock between factories.

Another further research area could be to include a contextual factor that encompasses the ecological aspect of inventory management. This would help firms chose a certain inventory configuration from a carbon footprint perspective and not solely a cost perspective.

\section{REFERENCES}

Alvarez, E., and M. van der Heijden, 2014, "On two-echelon inventory systems with Poisson demand and lost sales”, European Journal of Operational Research, 235: 334-338

Axsäter, S., C. Howard, and J. Marklund, 2013, "A distribution inventory model with transshipments from a support warehouse", IIE Transactions, 45: 309-322

Axsäter, S., 2005, "A simple decision rule for decentralized two-echelon inventory control", International Journal of Production Economics, 93-94: 53-59

Azzi, A., D. Battini, M. Faccio, A. Persona, and F. Sgarbossa, 2014, "Inventory holding costs measurement: a multi-case study", The International Journal of Logistics Management, Vol. 25 (1): 109-132

Babai, M.Z., A. Syntetos, and R. Teunter, 2014, "Intermittent demand forecasting: An empirical study on accuracy and the risk of obsolescence", International Journal of Production Economics, 157: 212-219

Barney J. B., M. Wright, D. J. Ketchen, 2001, “The resource based view of the firm: Ten years after 1991", Journal of Management, 27: 625-43. 
Braglia, M., and M. Frosolini, 2013, "Virtual pooled inventories for equipment-intensive industries. An implementation in a paper district", Reliability Engineering and System Safety, 112: 26-37

Bregni, A., M. D'Avino, V. De Simone, and M. M. Schiraldi, 2013, “Formulas of Revised MRP”, International Journal of Engineering Business Management, Vol. 5, 10:2013.

Chandler, A., 1962, "Strategy and Structure", The MIT Press, Cambridge, MA

Christopher, M., 2016, "Logistics and Supply Chain Management", Pearson Education Limited

Cohen, M. A., N. Agrawal, and V. Agrawal, 2009, "Winning in the Aftermarket", Harvard Business Review, p. $129-138$

Das, C. and R. Tyagi, 1997, "Role of inventory and transportation costs in determining the optimal degree of centralization", Transportation Research Part E, Vol. 33, No. 3, 171-179

Driessen, M., J. Arts, GJ van Houtum, J. W. Rustenburg and B. Huisman, 2015, "Maintenance spare parts planning and control: a framework for control and agenda for future research", Production Planning \& Control, 26:5, 407-426

Dyer, W.G., and A.L. Wilkins, 1991, "Better stories, not better constructs, to generate better theory: a rejoinder to Eisenhardt", Academy of Management Review, Vol. 16 (3): 613-619

Ghaddar, B., N. Sakr, and Y. Asiedu, 2016, "Spare parts stocking analysis using genetic programming", European Journal of Operational Research, 252: 136-144

Hahn, G.J., and A. Leucht, 2015, "Managing inventory systems of slow-moving items", International Journal of Production Economics, 170: 543 - 550

Hansen, Z.N.L, S.B. Larsen, A.P. Nielsen, N.G. Gregersen, A. Ghosh, and A. Groth, 2017, “Combining or Separating Forward and Reverse Logistics", International Journal of Logistics Management (Accepted)

Hill, T., A. Nicholson, and R. Westbrook, 1999, "Closing the gap: a polemic on plant-based research in operations management”, International Journal of Operations and Production Management, Vol. 19 (2): $139-156$

Hilmala, O-P., A. Hejazi, and L. Ojala, 2005, "Supply chain management research using case studies: a literature analysis", International Journal Integrated Supply Management, Vol. 1 (3): 294 - 311

Hopp, W. J., and M. C. Spearman, 2011, "Factory Physics", Waveland Press Inc., ISBN: 1-57766-739-5

Karsten, F., M. Slikker and GJ. van Houtum, 2012, "Inventory Pooling Games for Expensive, Low-Demand Spare Parts", Naval Research Logistics, 58: 311-324

Karsten, F., and R.J.I. Basten, 2014, "Pooling of spare parts between multiple users: How to share the benefits?", European Journal of Operational Research, 233: 94-104

Kennedy, W.J., J.W. Patterson, and L.D. Fredendall, 2002, “An overview of recent literature on spare parts inventories", International Journal of Production Economics, 76: 201-215

Kranenburg, A. A., and G. J. Van Houtum, 2007, "Effect of commonality on spare parts provisioning

Kuhn, T.S., 1996, "The Structure of Scientific Revolutions", The University of Chicago Press: Chicago and London

Kvale, S, 1996, "Inter Views: An introduction to qualitative research interviewing”, Thousand Oaks, CA: Sage.

Lee, H.L and C. Billington, 1993, "Material management in decentralized supply chains", Operations Research, Vol. 41 (5): $835-847$

Lengu, D., A.A. Syntetos, and M.Z. Babai, 2014, "Spare parts management: Linking distributional assumptions to demand classification", European Journal of Operational Research, 235: 624-635

Madadi, A., M. E. Kurz, and J. Ashayeri, 2010, "Multi-level inventory management decisions with transportation cost consideration", Transportation Research Part E, 46, 719-734

Malterud, K., 2012, "Systematic text condensation: A strategy for qualitative analysis", Scandinavian Journal of Public Health, 40: 795-805.

Meredith, J., 1998, "Building operations management theory through case and field research", Journal of Operations Management, Vol. 16 (4): 441-454

Mintzberg, H., 1979, "The structuring of Organizations: A synthesis of the Research", Prentice-Hall, Englewood Cliffs, NJ

Paterson, C., G. Kiesmüller, R. Teunter, and K. Glazebrook, 2011, "Inventory models with lateral transshipments: A review", European Journal of Operational Research, 210(2), 125-136.

Patterson, D. A., 2002, "A simple way to Estimate the Cost of Downtime", LISA conference 2002

Pertusa-Ortega, E. M., J. F. Molina-Azorín, and E. Claver-Cortés, 2010, "Competitive strategy, structure and firm performance", Management Decision, Vol. 48 (8): 1282 - 1303

Piplani, R., and Y. Fu, 2005, "A coordination framework for supply chain inventory alignment", Journal of Manufacturing Technology Management, Vol. 16 (6): 598 - 614

Porter, M. E., 1980, "Competitive Strategy: Techniques for Analyzing Industries and Competitors", New York: Free Press.

Protopappa-Sieke, M., and R.W. Seifert, 2010, "Interrelating operational and financial performance measurements in inventory control”, European Journal of Operational Research, 204(3), 439-448. 
Pyke, D.F. and Cohen, M.A. (1994), "Multiproduct integrated production-distribution systems", European Journal of Operational Research, Vol. 74, pp. 18-49.

Richardson, H., 1995, “Control your costs - Then cut them", Transportation \& Distribution, 36 (12): 94-96

Rowley, J., and F. Slack, 2004, “Conducting a literature review”, Management Research News, 27 (6): 31-39.

Rudi, N., S. Kapur, D. F. Pyke, 2001, "A two-location inventory model with transshipment and local decision making" Management Sci. 47 1668-1680.

Schmitt, A. J., S. A. Sun, L.W. Snyder, and ZJ. M. Shen, 2014, "Centralization versus decentralization: Risk pooling, risk diversification, and supply chain disruptions", Omega, 52, 201-212

Schonberger, R.L. and Knod, E.M. Jr, 1997, "Operations Management Customer-Focused Principles", Irwin/Mcgraw-Hill, Boston, MA.

Seidel, R., 1983, "Optimization of the availability of complex manufacturing systems - methods and examples", International Journal of Production Research, Vol. 21 (2), 153-162

Singha, K., P. Parthanadee, and J. Buddhakulsomsiri, 2015, “A comparison of Inventory Management between Decentralized and Centralized Distribution Networks with Backorder", Industrial Engineering, Management Science and Applications, Vol. 349, 485-490

Stoll, J., R. Kopf, J. Schneider, and G. Lanza, 2015, "Criticality analysis of spare parts management: a multicriteria classification regarding a cross-plant central warehouse strategy", Production Engineering, Vol. 9 (2); 225-235

Thomas, D.R., 2006, "A General Inductive Approach for Analyzing Qualitative Research Evaluation Data", American Journal of Evaluation, Vol. 27 (2), 237-246

Tiacci, L., and S. Saetta, 2010, "Reducing the mean supply delay of spare parts using lateral transshipments policies", International Journal of Production Economics, 133: 182-191

Tracht, K., M. Mederer, and D. Schneider, 2012, "Impact of Parameter Changes in a Service Provider ClosedLoop Supply Chain with Customer-Owned-Stock", $19^{\text {th }}$ CIRP International Conference on Life Cycle Engineering, Berkeley

van Hoek, R.I., A. Harrison, and M. Christopher, 2001, "Measuring agile capabilities in the supply chain", International Journal of Operations and Production Management, Vol. 21 (1/2): 126 - 148

van Wingerden, E., R.J.I. Basten, R. Dekker, W.D. Rustenburg, 2014, "More grip on inventory control through improved forecasting: A comparative study at three companies", International Journal of Production Economics, 157: 220-237

Voss, C., N. Tsikriktsis, and M. Frohlich, 2002, "Case research in operations management", International Journal of Operations \& Production Management, 22 (2): 195-219.

Vrat, P., 2014, "Material Management", Springer Texts in Business and Economics

Wacker, J.J., 1998, “A definition of theory: research guidelines for different theory building research methods in operations management", Journal of Operations Management, Vol. 16: 361-385

Wagner, S.M., R. Jönke, and A. B. Eisingerich, 2012, "A Strategic Framework for Spare Parts Logistics", California Management Review, Vol. 54, No. 4, 69 - 92

Wang, W., and S. Yue, 2015, “An inventory pooling model for spare units of critical systems that serve multicompanies", Transportation Research Part E, 76: 34-44.

Wanke, P.F., and E. Saliby, 2009, "Consolidation effects: Whether and how inventories should be pooled", Transportation Research Part E, 45, 679-692

Womack, D.T, and J.P. Jones, 1996, "Lean Thinking: Banish Waste and Create Wealth in Your Corporation, Touchstone, ISBN: 0684819767

Wong, H., D. van Oudheusden, and D. Cattrysse, 2006, "Cost allocation in spare parts inventory pooling", Transportation Research Part E, 43: 370-386

Yin, R.K., 1989, “The case study crisis: some answers”, Administrative Science Quarterly, Vol. 26 (1): 58-65

Yin, R.K., 1994, “Case Study Research: Design and Methods”, Sage Publications: Thousand Oaks, CA.

Zainal, Z., 2007, "Case study as a research method”, Jurnal Kemanusiaan, Vol. 9

Zeithaml, V. A., "Rajan” Varadarajan, P., \& Zeithaml, C. P., 1988, "The contingency approach: its foundations and relevance to theory building and research in marketing", European Journal of Marketing, 22(7): 3764

Zhao, R., V. Deshpande, and J.K. Ryan, 2005, "Inventory sharing and Rationing in Decentralized Dealer Networks", Management Science, 51 (4): 531-547 